\title{
DIGITALIZATION OF HEALTHCARE AND ETHICAL CHALLENGES OF COVID-19 PANDEMIC
}

\author{
Nezhmetdinova $\mathrm{F}^{1}{ }^{1}$, Guryleva $\mathrm{ME}^{2}$
}

${ }^{1}$ Kazan State Agrarian University, Kazan, Russia

${ }^{2}$ Kazan State Medical University, Kazan, Russia

By the end of the $20^{\text {th }}$ century, medicine was the first to fly into the digital world. New practices of medical data collection and storage appeared, the interrelation between a patient and all subjects of medical activity altered, automatization and robotization transformed many medical technologies, and legislation underwent significant changes. It resulted in new possibilities of rendering medical aid and occurring risks. The article deals with principal notions associated with digital medicine and determines its pressing issues. The basic reasons for updating digital transformation of medicine and its leading trends are reviewed including for the purpose of emergency situations such as COVID-19 pandemics. Closer attention is paid to the ethical issues that arise when digital technologies have been implemented and applied in the healthcare system. They include voluntary informed consent, confidentiality, ethics of digital control, safety, equality, data accessibility and protection. An important role of legal regulation and observance of bioethical principles is stressed.

Keywords: digital economy, digital transformation of medicine, digital healthcare, COVID-19 pandemic, risks, ethical issues, bioethics, law

Author contributions: Nezhmetdinova FT — study concept and design; editing of the final version of the manuscript. Guryleva ME — literature search and analysis; preparation of the manuscript draft.

$\triangle$ Correspondence should be addressed: Farida Nezhmetdinova

K. Marx 65, Kazan, 420015, Russia; nadgmi@mail.ru

Received: 05.08.2021 Accepted: 26.08.2021 Published online: 30.09.2021

DOI: $10.24075 /$ medet.2021.023

\section{ЦИФРОВИЗАЦИЯ МЕДИЦИНЫ И ЭТИЧЕСКИЕ ПРОБЛЕМЫ В УСЛОВИЯХ ПАНДЕМИИ COVID-19}

\author{
Ф. Т. Нежметдинова ${ }^{\bowtie}$, М. Э. Гурылёва²
}

${ }^{1}$ Казанский государственный аграрный университет, Казань, Россия

${ }^{2}$ Казанский государственный медицинский университет, Казань, Россия

\begin{abstract}
Медицина одной из первых с конца 20 века стремительно вошла в цифровой мир. Появились новые практики сбора и хранения медицинской информации, изменились взаимоотношения пациентаи всех субъектов медицинской деятельности, автоматизация и роботизация трансформировали многие медицинские технологии, серьёзно менялось законодательство. Как следствие, появились новые возможности, как оказания медицинской помощи, так и возникающие риски. В статье рассматриваются основные понятия, связанные с цисровой медициной и определяются её актуальные проблемы. Анализируются основные причины актуализации цифровой трансформации медицины и её основные направления, в том числе в контексте чрезвычайных ситуаций на примере пандемии COVID-19. Особое внимание уделяется этическим вопросам, возникающим в ходе внедрения и практики применения цифровых технологий в системе здравоохранения, таким как добровольное информированное согласие, конфиденциальность, этичность цифрового контроля, безопасность, равенство, доступность и защита данных, подчеркивается важная роль правового регулирования и соблюдения биоэтических принципов.
\end{abstract}

Ключевые слова: цифровая экономика, цифровая трансформация медицины, цифровое здравоохранение, пандемия COVID-19, риски, этические проблемы, биоэтика, право

Вклад авторов: Нежметдинова Ф. Т. - концепция и дизайн обзора, редактирование окончательного варианта рукописи; Гурылёва М. Э. - поиск и анализ литературных данных, подготовка первого варианта статьи.

$\bigotimes$ Для корреспонденции: Фарида Тансыковна Нежметдинова ул. К. Маркса, д.65, г. Казань, 420015, Россия; nadgmi@mail.ru

Поступила: 05.08.2021 Статья принята к печати: 26.08.2021 Опубликована онлайн: 30.09.2021

DOI: $10.24075 /$ medet.2021.023

Russia is exposed to the challenges of accelerating globalization and the technoeconomic paradigm shift. The $21^{\text {st }}$ century is emerging as an age of high technology and high standards of living. At the same time, public health protection and measures required for its implementation are now high on the agenda because of the global threat posed by the COVID-19 pandemic.

A global economic, legal and information system is being built strategically. Global competition is increasing not only in the traditional markets of goods, capital, technologies and labor but also between the systems of public administration, innovation support and development of human potential. Among the major global challenges of today are:

- a global shift to the new technoeconomic paradigm (Industry 4.0) and digital economy.

- accelerating technological transformation of the global economy. Russia is facing competition not only from the world leaders in innovation but also from developing countries and post-Soviet states.
- global intensification of competition for factors that determine the competitive ability of innovative systems, including highly skilled workforce, "smart" money (investments that bring innovative expertise, technologies and competencies into a project), education, and the sharp rise in their mobility.

- global challenges facing mankind: climate change, population ageing, public health issues, food safety.

All of these problems raise the need for new public health concepts.

In order to be prepared for digital economy and Industry 4.0 and to update a healthcare system accordingly, one needs to analyze these terms in form and substance.

In 1951, the British food manufacturing and catering company J. Lyons \& Co spearheaded the use of computers in business [1]. The Lyons Electronic Office (LEO) occupied a large room but was relatively primitive: today, a small hearing aid has more processing power and memory than LEO. However, LEO was able to 
calculate the output of the company's bakeries and the cost of the sold products faster than any human. Later, modernized versions of LEO were commissioned and used by Ford Motor Co, Kodak and other industrial giants. This was the first wave of the digital revolution that replaced human teams with systems capable of first simple and later more complex computations.

The second stage of the digital revolution is associated with the development of the new Industry 4.0 paradigm. This was clearly articulated at the 2016 World Economic Forum in Davos by its Executive Chairman Klaus Schwab in his report on the new industrial revolution [2]. Schwab described the Fourth Industrial Revolution as a synergy of technologies that blur the lines between physical, digital and biological dimensions. Advances in digital technologies, genetics, artificial intelligence, robotics, nanotechnologies, 3D printing, and biotechnologies are mutually amplifying. Special attention is being paid to "end-to-end" digital technologies that serve as a basis for technological convergence. According to Schwab, digitalization of all sectors of life and the advent of the second digital revolution have paved the way for a revolution of unprecedented scope. Smart systems (homes, factories, farms, networks, cities) will change the way we can tackle a wide range of problems, from managing a chain of supplies to dealing with climate change. The more profound is the change, the greatest opportunities it opens; the main challenges that require preventive adaptation measures from corporations, governments and individuals are associated with consumption, production and employment. Parallel to the technological revolution are other mutually reinforcing, multidirectional, interacting socioeconomic, geopolitical and demographic drivers of change.

In July 2017, the Committee for Strategic Development and Priority Projects approved the Digital Economy of the Russian Federation state program. President of Russia, Vladimir Putin, emphasized that digital economy would create novel models of business, trade, logistics and production, change the formats of education, public healthcare, management, and communication between people and thus set a new paradigm of development for the state, economy and society. Seeking to speed up the introduction of digital technologies into economy and social sectors and guided by the Executive Order 204 on the National Development Goals and Strategic Objectives of the Russian Federation through 2024, dated May 7, 2018, and Order 474 on the National Development Goals of the Russian Federation through 2030, dated July 21, 2020, the Russian Government formulated a national program Digital Economy of the Russian Federation, which was approved by the Presidential Council for Strategic Development and National Projects on June 4, 2019 (Protocol No.7) [3].

What is digital economy?

In 1995, the American computer scientist Nicholas Negroponte (Massachusetts Institute of Technology) coined the term "digital economy" to describe a shift from atoms to bits, opposing virtual reality (weightless bits) to actual raw materials that have weight and need to be transported [4]. Today, digital economy is understood as an element of economic relations mediated by the Internet, mobile networks and information and communication technologies (ICT). Its development is essential for the establishment of the cluster of basic technologies that form the emerging sixth technological paradigm. This cluster will transform almost every sphere of human activity, be it economic, social, politic, cultural, etc. The new technological paradigm is associated with the Fourth industrial revolution. In the first decade of its existence, which began in 1994, digital economy was largely based on e-commerce; now it spans the IT and financial sectors, education, public healthcare, state services, and so on.
The 2016 Digital dividends report issued by the World Bank described the global state of digital economy. Since then, the term "digital economy" has been eagerly used by politicians, entrepreneurs and journalists all over the world. However, it has not been clearly defined yet, even by the World Bank [5].

According to the broad definition proposed by Ivanov $\mathrm{V}$, Doctor of Economic Sciences and the corresponding member of the Russian Academy of Sciences, digital economy is a virtual environment supplementing reality. Prof. Meshcheryakov R (RAS) suggests there are two approaches to defining digital economy. According to the first (classical) approach, digital economy is an economy based on digital technologies and should be viewed as comprising exclusively the field of electronic products and services, such as telemedicine, distance learning and selling media content (films, TV programs, books, etc.) In the second approach, the definition is broadened to include production aided by digital technologies. Some experts think that this definition should also span the supply chains of products and services associated with the use of digital technologies, such as the Internet of things, Industry 4.0, smart factories, G5 mobile networks, engineering services, prototyping, etc. Professor Engovatova A. defines digital economy as an economy based on the novel methods of data generation, processing, storage and transmission, as well as on digital computer technologies [6].

The Digital economy in the Russian Federation state program defines digital economy as a management model involving the maximum use of computer technologies that can take the life of a person, relations of production, the structure of economy, and education to a totally new level [7].

In the modern world, where information is a fundamental resource, the amount of data generated every day is increasing at an exponential rate. This information revolution is being driven by the strategy of development centered around the individual and their changing needs.

Indeed, the strategy of digital economy in Russia is applied to public healthcare, too. New terms are emerging in the literature, including digital healthcare, a digital platform, digital medical care, digital medical services, a digital medicine ecosystem, and digital medical services infrastructure [8].

According to the experts of the Medtech portal [9], digital medicine contains the following elements:

- electronic document flow between the doctor, patient and medical organization;

- integration of digital diagnostic tools;

- a patient flow management system;

- an emergency care management system;

- use of telemedicine technologies;

- digital platforms for virtual health consultations between the doctor and the patient;

- remote patient monitoring using personal medical devices;

- use of mathematical methods for data processing, including $\mathrm{Al}$ and methods for processing large data arrays;

- development of information systems for medical diagnostics based on Al and large data arrays;

- development of decision support systems as auxiliary modules of medical information systems in the Internet of things, etc.

According to the WHO Regional Office for Europe, "digital health is a broad category encompassing electronic health, mobile health, telehealth and health data, among others. It offers solutions that can strengthen health systems, such as bringing health services directly to people's homes and to underserved communities, helping to map outbreaks of 
disease, and integrating digital tools that make health care more responsive and productive" [10].

At the global level, digitalization of healthcare aims to find solutions to such pressing issues as quality and availability of medical care across vast geographical territories, in remote areas and for low-income populations. Here, systemic digital technologies play an important role.

The large-scale implementation of information technologies in medicine and the pharmaceutical industry was triggered by the approval of the Resolution on eHealth at the $58^{\text {th }}$ World Health Assembly in 2005 [11]. Since then, the problems of digitalization and its ethical aspects have been discussed in medical communities and at international conferences, including those arranged by the International Society for Clinical Bioethics.

The WHO Symposium on the Future of Digital Health Systems in the European Region held in Denmark in 2019 was attended by 360 experts from 50 countries. Following the discussion on healthcare digitalization, its aspects and development strategies, 3 key conclusions were formulated:

"1. Digitalization is challenging our understanding of how and where healthcare can be delivered and is driving a transition to predictive and preventive models of care.

2. Digitalization of health systems is not simply a notion of continuing what we are doing now more rapidly and more efficiently but:

- puts the individual at the center of their own health and well-being;

- addresses how the rights and consent of the individual can be respected and acted on; and

- harnessing the value of data for health.

3. Digital health is centrally important to achieving universal health coverage with more efficient and effective modes of providing quality and equitable access to health for all. However, innovating towards a safe future enabled by digital health requires specifically linking investing for digital health with achieving public health objectives" [12].

At the international level, the HIMSS Analytics models and services have long been used to optimize healthcare. They formalize the process of exploiting information technologies to improve patient safety by creating tools for elaborating strategies for healthcare digitalization [13].

In Russia, the primary facilitator of healthcare digitalization (more specifically, digitalization of the internal workflow of medical organizations) is the Unified National Health Information System (abbreviated as EGISZ) [14]. A good example of successful digitalization is the Public Services Portal (Gosuslugi), which offers information and access to public services provided by the state and municipalities; using this portal, a patient can book an appointment with a doctor [15]. Another example is popular regional medical information services [16] and digital professional communities [17].

Digitalization of healthcare has revived an interest in ethical dilemmas, which determine the avenues of development for end-to-end technologies in healthcare, including vast data arrays, Al, automation, and robotics. Among such ethical issues are patient rights, responsibility of healthcare professionals, data processing and equality in healthcare.

A study [18] has identified 8 major problems related to digitalization:

1) big data (digital doppelgangers and falsifications);

2) transformation of the doctor-patient relationship;

3) digital literacy of patients;

4) responsibility in complex systems;

5) changes to medical specialties;

6) increasing costs and risk of overtreatment;
7) digital footprint;

8) role of clinical data in treatment and their protection.

Obviously, the implementation of such technologies has significantly transformed medical diagnostics, the system of prevention and treatment, and the relationship between the doctor and the patient. At the same time, the use of big data for Al training can result in manipulation, discrimination and human rights violation. However, by trying to constrain healthcare digitalization, we are slowing the progress in the field of medicine and diminishing the competitive ability of the Russian healthcare system.

So far, taking a history from a patient has been the gold standard in medicine. But only due to digitalization the amount of patient data increased dramatically and new opportunities opened for its storing, collecting and processing. Obviously, data related to a person's health and physical condition can be collected in different ways and may not always be associated with delivering medical care. The following data sources can be used in medicine:

- electronic medical records;

- mobile applications for healthcare (databases);

- sensors and monitoring devices;

- data generated by laboratory tests and radiography;

- data on past vaccinations and results of PCR tests available from Gosuslugi;

- data obtained in the course of clinical trials involving groups of patients;

- information about medications and other medical products purchased by patients;

- data from social media, search results, etc. [19]

According to experts, in order to effectively use Al for the prevention and treatment of diseases, more data is needed, both medical and social. This brings up an ethical issue of personal data protection, because strictly speaking this data is not medical.

Such data is available from different platforms and storage systems that are not always compatible with each other. Compatibility of storage systems, data verification, standardization and unification, as well as elaboration of ethical guidelines regulating their use, are needed to use such information for healthcare purposes.

The general principles of bioethics related to personal autonomy, confidentiality, the risk-benefit ratio, equality and healthcare availability play a special role in developing ethical guidelines for digital healthcare [20]. These principles have been most exhaustively documented in the Universal Declaration on Bioethics and Human Rights (UNESCO, 2005) [21].

Another great concern associated with the use of information technologies is their impact on human behavior and attitude to health. Digital technologies have come forward as a gauge of ethical behavior during a public health emergency, such as the current COVID-19 pandemic. With regard to human rights protection, which was high on the agenda during the pandemic, this problem necessitated development of new approaches to prevent the abuse of ethical principles. For example, the UK's Nuffield Council on Bioethics, the leading research center of bioethics, convenes a small group, should circumstances arise, to develop a separate "ethical compass" for each life-or-death situation [22].

The Russian state policy for countering epidemics restricts civil rights and freedoms listed in Chapter 2 of the Constitution and recognized as the supreme value [23]. Such violation of constitutional rights is justified by public safety. However, restrictions should not extend beyond necessity, result in the termination of international obligations of the state or be associated with discrimination of any sort. The pandemic raised the need for control over the daily lives of citizens, who had to 
give up some of their freedoms for the sake of public health. Following WHO's recommendations, many countries mandated testing for COVID-19, lockdowns, social distancing and other measures limiting physical interaction between individuals. That is when the unexpected controlling function of digital technologies came to light. This incited fear that digital technologies could be used as a coercion tool even after the current restrictions are lifted because digital technologies proved to be effective in controlling the safety of gatherings in public places, and this experience could be later applied to other activities. Opponents of strict measures disseminate false or misleading information and fake news via the Internet, which exacerbates the problem. This phenomenon became known as an infodemic, i. e. the fast spread of excessive information about the pandemic, often distorted or unreliable, through mass media and social networking services. The Internet itself is not the root of the problem, but through it rumors and fake news spread much faster and farther than ever before. At the same time, the Internet is an effective tool that governments, healthcare agencies and scientists should exploit to communicate important information to the general public. The Web Foundation has published a Covid Policy Brief containing guidelines for governments, companies and individuals on spreading accurate information, free exchange of opinions and knowledge sharing [24]. Based on the international standards in the field of human rights, these guidelines underscore the need for a thoroughly elaborated approach to balancing health protection, public safety, the freedom of expression and privacy [25]. Standardization of ethical practices in spreading information through different media sources could improve the situation.

Importantly, compliance with ethics is expected not only from healthcare professionals but also from the developers of software that utilizes Al, operators or other persons who gain access to personal data by virtue of their occupation; this involves the issues of patient confidentiality, the right for privacy and personal data protection $[23,26,27]$.

Defining ethics and deciding on what ethical guidelines to follow may be a challenge for those involved in designing, developing and implementing digital technologies for healthcare. There are various guidelines and restrictions aimed at regulating the impact of digital technologies on society. Software engineers who develop products for healthcare should follow the code of engineering and software ethics that apply to their work. In turn, development and implementation of digital technologies and applications for healthcare will determine what ethics is and what ethical principles should be adhered to. Thus, there is a need for creating the codes of ethics and professional conduct for new specialties that would combine ethical requirements for software, elements of engineering ethics and standards of medical ethics.

There is a plethora of foreign literature on various aspects of digital medicine. For example, a systematic review has been conducted to analyze the impact of using digital tools on the informed consent procedure in clinical research and practice. The researchers searched Pubmed, EMBASE and Cochrane electronic databases. Studies were identified using MeSH terms and keywords. The review included studies published from January 2012 to October 2020 and focusing on the use of digital informed consent tools for clinical research or medical interventions. Digital interventions were defined as interventions involving the use of multimedia or audio and video to provide information to patients. Those digital interventions were broken down in 3 categories: video, non-interactive multimedia and interactive multimedia. The literature search returned 19, 579 publications. After their titles and abstracts were screened for relevance, there were 100 publications selected for full-text analysis; of them 73 were included in the review. The included publications focused on interactive multimedia (29/73), non-interactive multimedia (13/73) and video (31/73); the majority of the studies had been performed on adults (34/38). Innovations in informed consent had been tested for clinical/surgical procedures (26/38) and clinical trials (12/38). For informed consent, 21 outcomes were analyzed; a positive effect on at least one of the studied outcomes was reported in 8/12 studies. For clinical/surgical procedures, 49 outcomes were analyzed; a positive effect on at least one of the studied outcomes was reported in 21 of 26 publications. The authors of the review concluded that the use of digital technologies for informed consent had not produced a negative effect on any of the outcomes, and multimedia tools were regarded as desirable. The effect of multimedia tools was more pronounced than that of videos. At the same time, the studies included in the review were heterogenous in design, which compounded the assessment. So, a robust design and standardization would be needed to perform further assessment [28].

Some foreign authors indicate that digital health products hold great promise for improving the quality of medical measurements, diagnostics and treatment. While many fields have embraced the digital revolution, public healthcare is yet to experience improvements, better access and economic effectiveness. Public healthcare lags behind other sectors partly because of the legislation, which usually slows the process as healthcare agencies are very cautious about the adverse consequences of digitalization [29].

Outside Russia, digital health studies are becoming increasingly widespread, partly due to the emergence of new concepts like "digital clinical trial" which involves the use of digital technologies for making the trial more accessible for the participants, promoting their involvement, improving the accuracy of measurements, ensuring blind randomization, etc. Digital technologies have a potential for transforming clinical trials and reducing their costs [30].

Summing up, in the modern world of progressive digitalization of healthcare and social services, the primary vulnerable spots in terms of ethics are data confidentiality, safety, equality, availability and protection.

Healthcare professionals are not the only ones affected by the implementation of digital technologies in medicine and healthcare. More people not bound by the code of medical ethics or legal medical obligations, including software developers, public servants, social and law enforcement workers, are gaining access to health data. This raises the need for creating the codes of professional conduct and updating legislation in the fields other than medical.

It is necessary to further refine the terms digital healthcare, digital medicine, digital medical services, digital clinical trial, etc. associated with the implementation of digital technologies because they are not clearly defined in the legislation, which makes the regulation of digital healthcare difficult.

Development of effective digital healthcare tools is an intense and complex process requiring interdisciplinary effort from a wide range of specialists, from engineers and ethics experts to tax payers and suppliers. Many problems are exacerbated by the interdisciplinary nature of digital healthcare. The progress of digital medicine slows down when the participants involved speak different languages and have different standards, experience and expectations.

Ethical standards for digitalization in healthcare should not be prohibitory. Instead, they should seek to regulate the sector and offer opportunities for development and implementation of end-to-end technologies, aiming to improve the quality of people's lives. 
1. Voitolovsky FG and Kuznetsov AV. The state in the era of globalization: economics, politics, security. World development. Issue 3. Moscow: IMEMO RAS, 2008; 219. Available from: https://www.imemo.r u/files/File/ru/publ/2008/08013.pdf" https:// www.imemo.r u/files/File/ru/publ/2008/08013.pdf. Russian.

2. Schwab K. The Fourth Industrial Revolution. M.: Eksmo 2016. http://ncrao.rsvpu.ru/sites/default/files/library/k._shvab_ chetvertaya_promyshlennaya_revolyuciya_2016.pdf. Russian.

3. Digital Economy 2024. Available from: https://digital.ac.gov.ru/ Russian.

4. Negroponte N. Being Digital. Knopf. Paperback edition. Vintage Books, 1996; 272 c

5. Digital dividends. World Bank Report. Available from: https://data gov.ru/sites/default/files/documents/vsemirnyy_bank_2016_god pdf Russian.

6. Digital Economy: how experts understand this term. Available from: https://ria.ru/science / 20170616/1496663946.htm (Accessed: 08.08.2021). Russian.

7. Digital Economy 2024. Available from: https://digital.ac.gov.ru/ Russian.

8. Karpov OE, Subbotin SA, Shishkanov DV, Zamyatin MN. Digital healthcare. Necessity and prerequisites. Doctor and Information Technology. 2017; (3): 6-22. Russian.

9. What is digital medicine? Available from: https://zdrav.expert/ index.php/\%D0\%A1\%D1\%82\%D0\%B0\%D1\%82\%D1\%8C\%D1 \%8F:\%D0\%A6\%D0\%B8\%D1\%84\%D1\%80\%D0\%BE\%D0\%B2 \%D0\%B0\%D1\%8F_\%D0\%BC\%D0\%B5\%D0\%B4\%D0\%B8\%D 1\%86\%D0\%B8\%D0\%BD\%D0\%B0 Russian.

10. WHO. Regional Office for Europe. Available from: https://www. euro.who.int/ru/health-topics/Health-systems/digital-health/news/ news/2020/9/digital-health-transforming-and-extending-thedelivery-of-health-services Russian.

11. Kugach W. Informatization of medicine and pharmacy in the American and African regions. Bulletin of Pharmacy. 2018; 2(80): 95-104. Russian.

12. The future of digital health systems. Report on the symposium "The Future of Digital Health Systems in the European region". Available from: https://apps.who.int/iris/bitstream/hand le/10665 /330370/9789289059985-rus.pdf Russian.

13. ABOUT HIMSS ANALYTICS. Available from: https://www. himssanalytics.org/about

14. Decree of the Government of the Russian Federation dated 05.05.2018 No. 555 (ed. dated 02.02.2019) "On the Unified State Information System in the field of healthcare"). Russian.

\section{Литература}

1. Войтоловский Ф. Г., Кузнецов А. В. Государство в эпоху глобализации: экономика, политика, безопасность. Мировое развитие. Выпуск 3. Ф. Г. А. В.М.: ИМЭМО РАН 2008; 219. Available from: https://www.imemo.ru/files/File/ru/ publ/2008/08013.pdf

2. Шваб К. Четвертая промышленная революция. М.: Эксмо 2016. Available from: http://ncrao.rsvpu.ru/sites/default/files/ library/k._shvab_chetvertaya_promyshlennaya_revolyuciya_2016. pdf

3. Цифровая экономика 2024. Available from: https://digital. ac.gov.ru/

4. Negroponte N. Being Digital. Knopf. Paperback edition. Vintage Books. 1996; 272 c

5. Цифровые дивиденды. Доклад Всемирного банка. Available from: https://data.gov.ru/sites/default/files/documents/vsemirnyy_ bank_2016_god.pdf

6. Цифровая экономика: как специалисты понимают этот термин Available from: https://ria.ru/science/ 20170616/1496663946. html (Дата обращения: 08.08.2021).

7. Цифровая экономика 2024. Available from: https://digital ac.gov.ru/
15. Website of Public Services. Available from: https://www.gosuslugi. ru/ Russian.

16. Health portal of the Republic of Tatarstan. Available from: https:// zdrav.tatar.ru/ Russian.

17. Unified portal. Doctor 42. Available from: https://www.vrach42 ru/ Russian.

18. Petrov IM, Spaderova NN, Maltseva ON, Egorov DB, Petrov DI. Ethical challenges of implementing "digital healthcare. Medical science and education of the Urals. 2019; (4): 203-20. Russian.

19. Gusev AV. Ethics of digital medicine. Available from: https://ethics. cdto.center/7_2 Russian.

20. Nezhmetdinova F. Global challenges and globalization of bioethics Croatian Medical Journal, 2013; 54 (1): 83-85. Available from: https://doi.org/10.3325/cmj.2013.54.83

21. "Universal Declaration on Bioethics and Human Rights" (UNESCO, 2005). Available from: https://www.un.org/ru/documents/decl_ conv/declarations/bioethics_and_hr.shtml Russian.

22. Nuffield's advice. Publications. Health and society. COVID-19. Available at: https://www.nuffieldbioethics.org/topics/health-andsociety/covid-19 Russian.

23. The Constitution (Basic Law) of the Russian Federation. Moscow, 2001. Russian.

24. Emily Sharpe. COVID-19 Policy Brief: Misinformation \& Freedom of Expression. London: World Wide Web Foundation. Available from. 2020: Available from: http://webfoundation.org/docs/2020/04/ Covid-Policy-Brief-Misinformation_Public.pdf

25. Nezhmetdinova FT, Guryleva ME. Medical, social and ethical problems related to COVID-19. Kazan Medical Journal. 2020; 101(6): 841-851 DOI:10.17816/KMJ2020-841 Russian.

26. On the protection of the population and territories from natural and man-made emergencies: Federal Law No. 68 of 21.12.1994. Russian.

27. On Technical Regulation: Federal Law No. 184-FZ of 27.12.2002. Russian.

28. Gesualdo F, Daverio M, Palazzani L. et al. Digital tools in the informed consent process: a systematic review. BMC Med Ethics. 2021;22:18 Available from: https://doi.org/10.1186/s12910-02100585-8 Russian.

29. Coravos A, Goldsack JC, Karlin DR, Nebeker C, Perakslis E, Zimmerman N, Erb MK. Digital Medicine: A Primer on Measurement Digit Biomark 2019; 3: 31-71. Available from: https://doi.org/10.1159/000500413

30. Inan OT, Tenaerts $P$, Prindiville SA, et al. Digitizing clinical trials. npj Digit. Med. 2020 Jul 31;3:101. Available from: https://doi. org/10.1038/s41746-020-0302-y

8. Карпов О. Э., Субботин С. А., Шишканов Д. В., Замятин М. Н. Цифровое здравоохранение. Необходимость и предпосылки. Врач и информационные технологии. 2017; (3): 6-22.

9. Что такое цифровая медицина. Available from: https://zdrav. expert/index.php/\%D0\%A1\%D1\%82\%D0\%B0\%D1\%82\%D1\%8 C\%D1\%8F:\%D0\%A6\%D0\%B8\%D1\%84\%D1\%80\%D0\%BE\%D0 \%B2\%D0\%B0\%D1\%8F \%D0\%BC\%D0\%B5\%D0\%B4\%D0\%B8 \%D1\%86\%D0\%B8\%D0\%BD\%D0\%B0

10. ВОЗ. Европейское региональное бюро. Available from: https:// www.euro.who.int/ru/health-topics/Health-systems/digital-health/ news/news/2020/9/digital-health-transforming-and-extendingthe-delivery-of-health-services

11. Кугач В. В. Информатизация медицины и фармации в американском и африканском регионах. Вестник фармации. 2018; 2(80): 95-104.

12. Будущее цифровых систем здравоохранения. Отчет о проведении симпозиума «Будущее цифровых систем здравоохранения в европейском регионе». Available from: https://apps.who.int/iris/bitstream/hand le/10665/330370/9789 289059985-rus.pdf 
13. ABOUT HIMSS ANALYTICS. Available from: https://www. himssanalytics.org/about

14. Постановление Правительства РФ от 05.05.2018 № 555 (ред. от 02.02.2019) «О Единой государственной информационной системе в сфере здравоохранения»).

15. Сайт Госуслуг. Available from: https://www.gosuslugi.ru/

16. Портал здравоохранения Республики Татарстан. Available from: https://zdrav.tatar.ru/

17. Единый портал. Врач 42. Available from: https://www. vrach42.ru/

18. Петров И. М., Спадерова Н. Н., Мальцева О. Н., Егоров Д. Б., Петров Д. И. Этические вызовы внедрения «цифрового здравоохранения». Медицинская наука и образование Урала. 2019; (4): 203-20.

19. Гусев А. В. Этика цифровой медицины. Available from: https:// ethics.cdto.center/7_2

20. Nezhmetdinova F. Global challenges and globalization of bioethics. Croatian Medical Journal, 2013; 54(1): 83-85. Available from: https://doi.org/10.3325/cmj.2013.54.83.

21. "Всеобщая декларация о биоэтике и правах человека" (ЮHECKO, 2005). Available from: https://www.un.org/ru/ documents/decl_conv/declarations/bioethics_and_hr.shtml

22. Совет Наффилда. Публикации. Здоровье и общество. COVID-19. Available from: https://www.nuffieldbioethics.org/ topics/health-and-society/covid-19
23. Конституция (Основной закон) Российской Федерации. Москва, 2001.

24. Emily Sharpe. Covid-19 Policy Brief: Misinformation \& Freedom of Expression. London: World Wide Web Foundation. Available from. 2020: Available from: http://webfoundation.org/docs/2020/04/ Covid-Policy-Brief-Misinformation_Public.pdf

25. Нежметдинова Ф. Т., Гурылёва М. Э. Медико-социальные и этические проблемы, связанные с COVID-19. Казанский медицинский журнал. 2020;101(6):841-851 DOI:10.17816/ KMJ2020-841

26. О защите населения и территорий от чрезвычайных ситуаций природного и техногенного характера: Федеральный закон от 21.12.1994 № 68.

27. О техническом регулировании: Федеральный закон от 27.12.2002 № 184-Ф3.

28. Gesualdo F, Daverio M, Palazzani, L, et al. Digital tools in the informed consent process: a systematic review. BMC Med Ethics. 2021;22:18 Available from: https://doi.org/10.1186/s12910-021-00585-8

29. Coravos A., Goldsack J. C., Karlin D. R., Nebeker C., Perakslis E., Zimmerman N., Erb M. K. Digital Medicine: A Primer on Measurement Digit Biomark 2019; 3: 31-71 Available from: https://doi.org/10.1159/000500413

30. Inan O. T., Tenaerts P., Prindiville S. A. et al. Digitizing clinical trials. npj Digit. Med. 2020 Jul 31;3:101. Available from: https:// doi.org/10.1038/s41746-020-0302-y 